\title{
Working Capital Management and Corporate Performance: Evidence from Sri Lankan Listed Manufacturing Firms
}

\author{
Ratnam Vijayakumaran (Corresponding author) \\ Department of Financial Management, Faculty of Management Studies and Commerce \\ University of Jaffna, Sri Lanka \\ E-mail: rvijay@univ.jfn.ac.lk
}

Sunitha Vijayakumaran

Department of Management Studies

The Open University of Sri Lanka, Sri Lanka

Received: March 14, 2017 Accepted: October 25, 2017 Published: December 31, 2017

doi:10.5296/ijafr.v7i2.12453 URL: https://doi.org/10.5296/ijafr.v7i2.12453

\begin{abstract}
Working capital that represents a significant portion of a firm's total assets affects its profitability and liquidity. This study examines the performance effects of working capital management using a panel of listed manufacturing companies on the Colombo Stock Exchange (CSE) over the period 2011 to 2016. Controlling for unobservable firm specific heterogeneity and a set of observable firm characteristics, we document that working capital is non-linearly (inverted U-shaped) related to firm profitability. This indicates the existence of an optimal level of working capital that balances the costs and benefits of maintaining working capital, and maximizes firm's performance.
\end{abstract}

Keywords: Working capital management, Cash conversion cycle, Net trade cycle, Profitability, Sri Lanka

JEL Classification: D22, G31, G32 


\section{Introduction}

Working capital (WC) represents a significant portion of firms' investment and efficiency of working capital management affects profitability and liquidity of the firms (Lamberson, 1995; Aktas, Croci \& Petmezas, 2015). The working capital is defined as the difference between firms' current assets and current liabilities. By efficiently managing WC, firms can minimize the amount of funds tied up in current assets and thus are able to reduce financing costs and/or increase the funds available for long term investment. Efficient management of WC is crucial for all firms, regardless of their size. WC represents a firm's liquidity position and thus it not only provides a signal of a firm's operating liquidity but also its future credit-worthiness. Efficient management of WC is important for large firms because it affect their ability to borrow, pay routine expenses and short-term debts and create value for their owners. On the other hand, it is even important for small firms that are more likely to face constraints in accessing financial markets to borrow, and for start-ups in order to ensure their survival until they break even. Smith (1978) notes that the poor working capital management is the main reason for the failure of most firms. Thus, Shin and Soenen (1998) suggest that efficient working capital management is an integral part of the overall corporate strategy to create shareholder value.

Working capital management has gained much attention as a field of research after the recent global financial crisis (2007-2008). Empirical research also provide evidence consistent with the view that efficient management of working capital is important not only for improving accounting performance but also for creating value for shareholders (Shin \& Soenen, 1998; Deloof, 2003; Hill, Kelly \& Highfield, 2010; Kieschnick, Laplante \& Moussawi, 2013; Aktas et al., 2015).

In corporate finance, the most conventional measures used to measure a company's liquidity position are the current ratio and the quick ratio. Due to their static nature, these liquidity measures were considered as inadequate to measure a firm's efficiency in managing its working capital (e.g., Kamath, 1989). Therefore, Gitman (1974) introduced the cash conversion cycle concept as an important element in working capital management. Since then, the cash conversion cycle (CCC) has been used as the standard measure for working capital management in the text books and empirical research. Cash conversion period basically reflects the time span between disbursement and collection of cash. It is measured by the sum of the inventory conversion period and the receivable conversion period, less the payables conversion period. The shorter the CCC, the more efficient the firm is in managing its working capital because it turns its working capital over more times a year and thus allows it to generate more sales per money invested.

Manufacturing companies play a major role in the economic development of Sri Lanka through their significant contributions to the national income particularly in its exports (Pandey, Gupta \& Perera, 1997; Perera, \& Wickremasinghe, 2010). Yet, the Sri Lankan nascent capital market is characterized by high level of asymmetric information and agency problems like other Asian capital markets compared with that of developed countries and thus, the flow of additional capital is rather restricted for the firms in Sri Lanka (Perera \& 


\section{Mll Macrothink}

International Journal of Accounting and Financial Reporting ISSN 2162-3082 2017, Vol. 7, No. 2

Wickremasinghe, 2010; Eswaran, 2015; Vijayakumaran, 2015; Dixon, Guariglia, \& Vijayakumaran, 2015). Therefore, it becomes vitally important for the firms in Sri Lanka to manage working capital efficiently and release the fund that may be unnecessarily tied up in working capital to the expansion of their operations.

Previous empirical research has focused on the impact of working capital management on profitability of listed manufacturing firms in Sri Lanka (e.g., Nimalathasan, 2010; Koperunthevi, 2010; Jahfer, 2015). While most of these studies fail to control for firm specific unobserved heterogeneity (except Jahfer (2015)), none of these studies examines the potential non-linear relationship between working capital management and profitability of the firms (Baños-Caballero, García-Teruel, \& Martínez-Solano, 2014). Therefore, the main contribution of this study is to examine the potential non-linearities between working capital management and profitability for the manufacturing listed firms in Sri Lanka. Using a panel of 174 firm year observations over the period 2011 to 2016, our study finds an inverted U-shaped relationship between working capital and firm performance.

The reminder of the paper is organized as follows. Section 2 reviews relevant literature and develops hypothesis. The model specification and estimation methods are discussed in Section 3. Section 4 describes the data and descriptive statistics. Section 5 discusses empirical results. Section 6 concludes.

\section{Review of the Literature and Hypothesis}

\subsection{Working Capital Management and Firm Performance}

As Shin and Soenen (1998) pointed out, a corporation's working capital is the result of the time lag between the expenditure for the purchase of raw materials and the collection from the sale of finished goods. As such, Schiff and Lieber (1974), Sartoris and Hill (1983), and Kim and Chung (1990) all demonstrate the importance of considering the joint effect of the various components of working capital management, namely, receivable accounts, inventories and payable accounts. The prior empirical literature, therefore, focuses on overall working capital management in addition to individual components of WCM. Although there is no a single comprehensive theory to explain the link between overall WCM and corporate performance, there is substantial literature linking the components of WCM (i.e., credit policy and inventory management) and firm performance.

Lewellen, McConnel, and Scott (1980) show that under perfect financial markets, trade credit decisions do not affect firm value. However, the subsequent literature provides several theoretical arguments consistent with the view that in the presence of market frictions such asymmetric information and moral hazard problems, etc., the trade credit and inventories affect firm value (see, for example, Brennan, Maksimovic, \& Zechner,1988; Long, Malitz \& Ravid, 1993; Deloof \& Jegers, 1996; Bao \& Bao, 2004; Emery, 1984). Long et al. (1993) developed a model of trade credit which shows that to reduce the asymmetric information between buyer and seller and thus to increase sales, good firms extend trade credit to their clients so that they can verify quality of product and services prior to payment. In addition, granting trade credit might help to increase a firm's sales, as it can serve as an effective price 
cut (i.e., an inexpensive source of credit for customers (Brennan et al., 1988; Petersen \& Rajan, 1997); as it strengthens long-term supplier-customer relationships ( $\mathrm{Ng}$, Smith, \& Smith, 1999; Wilner, 2000), and as it encourages customers to acquire merchandise at times of low demand (Emery, 1987). Furthermore, trade credit serves as an important supplier selection criterion when it is hard to differentiate products (Shipley \& Davis, 1991; Deloof \& Jegers, 1996). Finally, Emery (1984) point out that granting trade credit is a more profitable short-term investment than marketable securities.

Second important element of WCM is management of inventories. Blinder and Maccini (1991) suggest that holding larger inventories enables firms to reduce supply costs, hedge against price fluctuations, avoid interruptions in the production process and thus minimize loss of customers and business due to potential stock-outs. (Blinder \& Maccini, 1991; Fazzari \& Petersen, 1993)

By contrast, there are also possible adverse effects of keeping excess investment in working capital. For instance, granting generous trade credit and holding larger inventories means that money is locked up in working capital which may negatively affect firm performance by eroding the ability of firms to undertake other value-enhancing investment projects in the short run (Deloof, 2003; Ek \& Guerin, 2011). Stock holding costs such as warehouse rent, insurance and security expenses also rise as the level of inventory increases (Kim \& Chung, 1990). Furthermore, firms with a greater level of working capital face more interest expenses (Kieschnick et al., 2013) and as such, these firms are more likely to experience financial distress and face the threat of bankruptcy.

In sum, the potential positive and negative effects of working capital suggest that the working capital decisions involve a trade-off. Therefore, firms seek to maintain an optimal level of working capital that maximizes their performance or shareholders wealth.

\subsection{Prior Evidence on the Relationship Between WCM and Corporate Performance}

In this subsection, we review related prior works analyzing the performance effect of WCM. Using a COMPUSTAT sample of 58,985 firm year observations over the period 1975-1994, Shin and Soenen (1998) report a strong negative contemporaneous relation between WCM and corporate profitability and risk-adjusted stock returns, suggesting that that one possible way to improve profitability and create shareholder value is to enhance the efficiency of WCM. Similarly, Deloof (2003) use a sample of 1,009 large Belgian non-financial firms for a period of 1992-1996 to examine the relationship between working capital management and corporate profitability. Following Shin and Soenen (1998), he uses correlation and regression analysis to test the relationship. Although his study finds no significant relationship between CCC and profitability, he reports a significant negative relationship between gross operating income and the number of days accounts receivable, inventories, and accounts payable of Belgian firms, implying that managers can increase profitability of their firms by reducing the number of day's inventories and accounts receivable. Lazaridis and Tryfonidis (2006) use a sample of 131 firms listed on the Athens Stock Exchange for the period of 2001 - 2004 and find statistically significant relationship between profitability (gross operating profit), and the cash conversion cycle and its individual components (accounts receivables, accounts 
payables, and inventory). They use correlation and cross sectional regression to tests the hypotheses. Their study suggests that managers can improve profitability of their companies by efficiently managing the cash conversion cycle and its components (accounts receivables, accounts payables, and inventory) at an optimal level. Banos-Caballero et al. (2012) use a sample of small and medium-sized Spanish firms, and report a negative relationship between cash conversion cycle and operating performance. Focusing on a sample of 52 non-financial firms of Amman stock market over the period 2000 to 2008, Abuzayed (2012) examines the relationship between WCM and firm performance using two performance measures, namely, accounting measure (profitability) and market measure (Tobin Q). Abuzayed (2012) finds that efficient WCM improves both profitability and market value of the firms.

More recently, empirical research has focused on the potential nonlinear relationship between WCM and corporate performance. For example, Banos-Caballero et al. (2014) focus on a sample of UK firms and find a non-linear (inverted U-shaped) relationship between NWC and stock performance, suggesting that NWC is positively related to performance at lower levels of NWC whereas NWC is negatively related to performance at higher levels of NWC.

In the context of Sri Lanka, only a few studies have examined the impact of working capital on corporate performance. For example, focusing on a sample of listed manufacturing companies in Sri Lanka, Nimalathasan (2010) and Koperunthevi (2010) among others report that working capital management (measured by CCC) is inversely related to profitability of the firms. More recently, Jahfer (2015) examines the effect of working capital management on profitability using a sample of Sri Lankan listed manufacturing companies over the period 2008 to 2013. He uses both pooled ordinary least square and fixed effects model to test the relationship. Although he finds no significant relationship between CCC and firm's profitability, finds a negative relation between NTC and profitability. Although former studies do not control for potential unobserved heterogeneity that affect corporate profitability, Jahfer (2015) uses fixed effects model to control for firm specific unobserved heterogeneity. However, none of these studies examines the potential non-linear relationship between working capital management and profitability of the firms although prior studies provide evidence suggesting that working capital management is nonlinearly related to corporate performance (Banos-Caballero et al., 2014). Therefore, this study contributes to the literature by examining the potential non-linear relationship between working capital management and profitability for the manufacturing listed firms in Sri Lanka.

\subsection{Hypothesis}

As a whole, the theoretical arguments and prior empirical findings suggest the non-linear relationships between working capital management and profitability. That is, as we discussed above, since the working capital decisions involve a trade-off, firms seek to maintain an optimal level of working capital that balances the costs and benefits and maximizes their value. Therefore, we would expect that at lower levels of $\mathrm{WC}$, corporate performance to rise as working capital increases. Yet, after an optimal level is reached, a further increase in WC negatively affects corporate performance, suggesting that at higher levels of WC, there should be an inverse relationship between a firm's CCC and its profitability. We therefore 
hypothesize that:

H1: There is a non-linear (inverted U-shaped) relationships between a firm's working capital and its profitability.

\section{Model Specification and Estimation Methodology}

\subsection{Model Specification}

We estimate following panel data regression model that links corporate performance with working capital management and firm characteristics:

$$
R O A_{i t}=\beta_{0}+\beta_{1} C C C_{i t}+\beta_{2} C C C^{2}{ }_{i t}+\beta_{3} S I Z E_{i t}+\beta_{4} L E V_{i t}+\beta_{4} S G R W_{i t}+v_{i}+v_{t}+\varepsilon_{i t}
$$

where $i$ indexes firms, $t$ years. Table 1 provides definitions for all variables used in this paper. The error term in Equation (1) is made up of three components: $v_{i}$ is a firm-specific effect; $v_{t}$, is a time-specific effect, which we control for by including time dummies capturing business cycle effects and $\varepsilon_{i t}$ is an idiosyncratic component.

\subsubsection{Dependent Variables}

In this study we use two alternative proxies to measure corporate performance, namely return on assets $(R O A)$ and return on equity $(R O E)$. While $R O A$ is defined as net income (net profit) divided by total assets, $R O E$ defined as net income divided by total equity.

\subsubsection{WCM Variables}

The main independent variable is the cash conversion cycle (denoted by $C C C$ ) which is used as a comprehensive measure to capture the effect of firms' working capital management on corporate performance (Deloof, 2003). The CCC links the time needed by firms to collect cash from customers with the time necessary in order to repay suppliers into one single measure (Deloof, 2003). The cash conversion cycle is calculated as the sum of number of days accounts receivable plus number of days inventory minus number of days accounts payable. Following Ding, Guariglia and Knight (2013), the components of CCC are calculated as follows. Number of day's accounts receivable is calculated as a ratio of accounts receivable times 365 divided by sales. Number of day's inventories is calculated as a ratio of inventories times 365 divided by cost of sales. Number of days accounts payable is a ratio of accounts payable times 365 divided by cost of sales.

In addition, we use net trade cycle $(N T C)$ as an alternative measure of WCM. The NTC is similar to the $C C C$ except all three components (number of days accounts receivable, number of days inventory and number of days accounts payable) are expressed as a percentage of sales. The NTC thus provides an estimate for additional financing needs pertaining to working capital expressed as a function of the projected sales growth (Shin \& Soenen, 1998).

\subsubsection{Control Variables}

In line with prior literature, in addition to WCM variables, a set of control variables are included in the regressions to control for firm-specific observable characteristics that are likely to be correlated with firms' performance. There are firm size (SIZE) measured by the natural 


\section{Ml Macrothink}

International Journal of Accounting and Financial Reporting

ISSN 2162-3082

2017, Vol. 7, No. 2

logarithm of sales, sales growth $(S G R W)$ measured by the ratio of changes in sales to previous year's sales ([this year's sales - previous year's sales]/previous year's sales), and finally, the ratio of total debt to total assets $(L E V)$.

Table 1. Definitions of variables

\begin{tabular}{|c|c|c|}
\hline Variables & Acronyms & Measurement \\
\hline \multicolumn{3}{|l|}{ Dependent Variables } \\
\hline \multirow[t]{2}{*}{ Performance } & $R O A$ & Return on assets: Net income/ Total assets \\
\hline & $R O E$ & Return on equity: Net income/ Total equity \\
\hline \multicolumn{3}{|l|}{ WCM Variables } \\
\hline \multirow[t]{2}{*}{ Cash conversion cycle } & $C C C$ & $\begin{array}{l}\text { Aggregation of receivables, inventory and payables } \\
\text { days }\end{array}$ \\
\hline & $C C C^{2}$ & Square of $C C C$ \\
\hline Accounts receivable days & $A R D$ & (Accounts receivables/sales) $* 365$ \\
\hline Inventory days & $I N V$ & (Inventories/ cost of sales) $* 365$ \\
\hline Accounts payables days & $A P D$ & (Accounts payables/ cost of sales)*365 \\
\hline \multirow[t]{2}{*}{ Net trade cycle } & NTC & $\begin{array}{l}\text { (Accounts receivables + Inventory - Accounts } \\
\text { payables) } * 365 / \text { (Sales) }\end{array}$ \\
\hline & $N T C^{2}$ & Square of $N T C$ \\
\hline \multicolumn{3}{|l|}{ Control variables } \\
\hline Firm size & SIZE & The natural logarithm of total sales \\
\hline Leverage & $L E V$ & Total debt divided by total assets \\
\hline Sale growth & $S G R W$ & $\left(\right.$ Sales $_{t}-$ Sales $\left._{t-1}\right) /$ Sales $_{t-1}$ \\
\hline Year dummies & $v_{t}$ & Year dummies for the years 2012 to 2016. \\
\hline
\end{tabular}

\subsection{Estimation Methodology}

To examine the relationship between WCM and corporate performance, we use the panel data methodology. We first use a pooled OLS (Ordinary Least Square) model. (Note 1) However, a pooled OLS does not take into account the potential unobserved firm heterogeneity, for example, managerial ability (Zwiebel, 1996), which may affect both the firm's working capital management and performance. Therefore, we use fixed effects method which allows us to control for unobservable heterogeneity and, therefore, eliminates the risk of obtaining biased estimates for our variables.

\section{Sample and Descriptive Statistics}

\subsection{Sample and Data Set}

The data used in this study are obtained from annual reports of individual companies listed on the Colombo Stock Exchange (CSE) for the period of 2010-2016. The sample is composed of 33 the publicly listed manufacturing firms for which all the data are available for each year of the sample period. To reduce the influence of potential outliers, we exclude observations in the 
one percent tails of each of the regression variables. We then benchmarked the trimmed data with descriptive statistics reported in other papers to ensure that the sample was representative of the population of non-financial firms listed on the CSE. After this screening and computation of the variables, we end up with panel of 174 firm-year observations over the period 2011-2016 for our empirical analysis.

\subsection{Descriptive Statistics}

Table 2 presents descriptive statistics for the variables used in the analysis for our pooled sample. The pooled mean (median) return on assets (ROA) and return on equity (ROE) are $9 \%(6.5 \%)$ and $15.2 \%(12.5 \%)$, respectively. Average cash conversion cycle $(C C C)$ and net trade cycle $(N T C)$ are 68.3 days and 61.9 days, respectively, with a median value of about 56 days for both CCC and NTC. As for the control variables included in our regression model, average size (SIZE) of the manufacturing firms measured by sales is about 4.38 billion rupees (3.42 billion rupees) (Note 2). The average (median) total debt to asset ratio $(L E V)$ is $48.7 \%$ (47\%), suggesting that about $49 \%$ of the manufacturing firms' assets are financed by debt capital. Finally, the average (median) sales growth $(S G R W)$, proxied by changes in sales, is $13.2 \%(11.8 \%)$.

These summary statistics indicate that the sample used in this study is comparable to that of prior research on WCM in Sri Lanka.

Table 2. Summary statistics

\begin{tabular}{lcrrrrr}
\hline Variables & Obs & \multicolumn{1}{c}{ Mean } & Std. Dev. & \multicolumn{1}{c}{ Median } & \multicolumn{1}{c}{ Min } & \multicolumn{1}{c}{ Max } \\
\hline Return on assets $(R O A)$ & 174 & 0.090 & 0.097 & 0.065 & -0.055 & 0.459 \\
Return on equity $(R O E)$ & 174 & 0.152 & 0.144 & 0.125 & -0.095 & 0.671 \\
Cash Conversion Cycle $(C C C)$ & 174 & 68.358 & 51.621 & 56.473 & 1.205 & 222.122 \\
Net Trade Cycle (NTC) & 174 & 61.927 & 42.159 & 56.289 & 2.199 & 170.453 \\
Firm size (SIZE) (Rs. billion) & 174 & 4.380 & 4.270 & 3.420 & 1.580 & 14.510 \\
Leverage $($ LEV $)$ & 174 & 0.487 & 0.136 & 0.470 & 0.160 & 0.750 \\
Sales growth $(S G R W)$ & 174 & 0.132 & 0.313 & 0.118 & -0.463 & 0.98 \\
\hline
\end{tabular}

Notes: This table reports summary statistics of the variables used in our study. All variables are defined in Table 1. It should be noted that although firm size is measured as the natural logarithm of total sales in the regression analysis, the figures reported in Table 2-the descriptive statistics are not in logarithms but as actual values. Furthermore, following Shin and Soenen (1998), CCC and NTC which are divided by 100 are used in the regression analysis. 


\section{MlMacrothink}

\section{Empirical Results}

\subsection{Correlation Analysis}

Table 3 reports Pearson correlation coefficients between variables considered in this study. These correlations exhibit some simple relations among the variables before moving to the regression results. First, both measures of WCM, namely $C C C$ and NTC show a negative and statistically significant correlation with firm's performance measured by both ROA and ROE. This result is consistent with the findings of previous studies, for example Shin and Soenen (1998), Abuzayed (2012). Turning to control variables, firm size (SIZE) has a significant positive correlation with both $R O A$ and ROE. Total leverage (LEV) is significantly and negatively associated with $R O A$ but not significantly related to $R O E$. Finally, sales growth $(S G R W)$ exhibits an insignificant correlation with both measures of profitability. Furthermore, Table 3 indicates that since the observed correlation coefficients between predictor variables are relatively low, multicollinearity should not be a serious problem in our study.

Table 3. Correlation matrix

\begin{tabular}{lccccccc}
\hline & $R O A$ & $R O E$ & $C C C$ & NTC & SIZE & LEV & SGRW \\
\hline$R O A$ & 1.00 & & & & & & \\
$R O E$ & $0.96^{*}$ & 1.00 & & & & & \\
$C C C$ & $-0.08^{*}$ & $-0.03^{*}$ & 1.00 & & & & \\
$N T C$ & $-0.13^{*}$ & $-0.08^{*}$ & $0.96^{*}$ & 1.00 & & & \\
SIZE & $0.33^{*}$ & $0.36^{*}$ & 0.09 & 0.08 & 1.00 & & \\
$L E V$ & $-0.29^{*}$ & -0.09 & $0.29^{*}$ & $0.31^{*}$ & $0.27^{*}$ & 1.00 & \\
SGRW & -0.00 & 0.00 & 0.02 & 0.01 & 0.09 & 0.04 & 1.00 \\
\hline
\end{tabular}

Notes: This table reports Pearson correlation coefficients. * denotes significance at the 5\% level or more. See Table 1 for definitions of all variables.

\subsection{Multivariate Analysis}

Table 4 presents estimation results of our regression model (1) where the dependent variable namely, return on assets (ROA) is regressed on $C C C, C C C$ squared and a set of control variables including firm size, leverage, sales growth and a set of year dummies. While Column (1) reports the pooled OLS estimates (which does not include $v_{i}$ component, a firm-specific fixed effect) and Column (2) reports estimation results of fixed effects estimator. Since we observe similar results from both the regressions, we focus discussion on the fixed effects regression results, Firstly, the coefficient of $C C C$ is positive and significant at the 5\% level and the coefficient of square of $C C C$ is negative and significant at the 5\% level. These results provide strong evidence to support our hypothesis $(H 1)$ that there is a non-monotonic relationship between $C C C$ and corporate performance (i.e., an inverted U-shaped relationship between the $C C C$ and $R O A$ ). Specifically, the profitability (ROA) first increases, then decreases as levels of WC rise. This implies that at lower levels of working capital, the 
positive effect of WC arising from higher sales and discounts for early payments dominates any negative effects; but at working capital levels above the optimum, the adverse effect of WC arising from opportunity cost and financing cost and etc. dominates. Therefore, the relation between working capital and firm performance is positive at lower levels of WC and it becomes negative at higher levels of WC. The average turning point in CCC is 102days. These findings are consistent with the findings of Banos-Caballero et al. (2014) for UK firms.

Table 4. Relationship between WCM (CCC) and corporate performance

\begin{tabular}{|c|c|c|}
\hline & OLS & Fixed effects \\
\hline \multirow[t]{2}{*}{$C C C$} & $0.065 * * *$ & $0.075^{* *}$ \\
\hline & (3.19) & $(2.28)$ \\
\hline \multirow[t]{2}{*}{$C C C^{2}$} & $-0.032 * *$ & $-0.038 * *$ \\
\hline & $(-2.12)$ & $(-2.04)$ \\
\hline \multirow[t]{2}{*}{ SIZE } & $0.038 * * *$ & $0.033 * *$ \\
\hline & $(4.77)$ & $(2.11)$ \\
\hline \multirow[t]{2}{*}{$L E V$} & $-0.314 * * *$ & $-0.288 * * *$ \\
\hline & $(-4.2)$ & $(-4.14)$ \\
\hline \multirow[t]{2}{*}{$S G R W$} & -0.019 & -0.004 \\
\hline & $(-0.68)$ & $(-0.24)$ \\
\hline \multirow[t]{2}{*}{ Constant } & $0.590 * * *$ & 0.339 \\
\hline & $(3.89)$ & $(0.89)$ \\
\hline Year fixed effect & Yes & Yes \\
\hline Firm fixed effect & No & Yes \\
\hline Inflection & 101.56 Days & 98.68 Days \\
\hline Adj. $R^{2}$ & 39.35 & 33.69 \\
\hline $\mathrm{F}$ test ( $p$-value) & $4.18(0.000)$ & $3.69(0.000)$ \\
\hline
\end{tabular}

See Table 1 for definitions of all variables. Asterisks denote statistical significance at the $1 \%$ $(* * *), 5 \%(* *)$, or $10 \%(*)$ level, respectively. The figures reported in parentheses are t-statistics. In regression analysis. CCC and NTC are divided by 100.

Turning to the control variables, we observe that the estimated coefficient on firm size (SIZE) is positive and significant at the 5\% level, suggesting that large firms enjoy economies of scale and are thus positively associated with profitability $(R O A)$. This finding is consistent with the finding of Jahfer (2015). The coefficient associated with leverage is negative and highly significant (at the $1 \%$ level). Finally, sales growth $(S G R W)$ is not significantly associated with firm performance at conventional levels. This finding is consistent with the finding of Jahfer (2015). 


\section{Macrothink}

International Journal of Accounting and Financial Reporting ISSN 2162-3082

The adjusted $R^{2}$ (in Column 2) suggests that $33.69 \%$ of the total variance of the performance (ROA) is explained by the model.

\subsection{Robustness Tests}

As a robustness test, we estimate the regression model (1) with net trade cycles (NTC) and its square as the main independent variables instead of $C C C$ and its square, using both the pooled and fixed effects regressions. The estimation results are reported in Columns 1 and 2 of Table 5, respectively.

Table 5. Relationship between WCM (NTC) and corporate performance

\begin{tabular}{lll}
\hline & OLS & Fixed effects \\
\hline$N T C$ & $0.087^{* *}$ & $0.098^{* *}$ \\
$N T C^{2}$ & $(2.13)$ & $(2.09)$ \\
& $-0.059^{* *}$ & $-0.065^{* *}$ \\
SIZE & $(-2.15)$ & $(-1.99)$ \\
& $0.038^{* * *}$ & $0.034 * *$ \\
$L E V$ & $(4.79)$ & $(2.17)$ \\
& $-0.291^{* * *}$ & $-0.315^{* * *}$ \\
$S G R W$ & $(-3.75)$ & $(-4.51)$ \\
& -0.022 & 0.002 \\
Constant & $(-0.75)$ & $(0.10)$ \\
& $0.607^{* * *}$ & 0.341 \\
Year fixed effects & $(3.66)$ & $(0.694)$ \\
Firm fixed effects & Yes & Yes \\
Inflection & No & Yes \\
Adj. $R^{2}$ & 73.73 days & 75.38 days \\
F teat $(p$-value) & 32.34 & 32.71 \\
\hline
\end{tabular}

See Table 1 for definitions of all variables. Asterisks denote statistical significance at the $1 \%$ $(* * *), 5 \%(* *)$, or $10 \%(*)$ level, respectively. The figures reported in parentheses are t-statistics.

As can be seen in Table 5, the results show that the coefficients on NTC and its square are significant at the 5\% level in both the Columns. The former is positive and the latter negative. These findings once again confirm that in line with hypothesis $\mathrm{H} 1$, there is a curvilinear (inverted U-shaped) relationship between working capital management measured by NTC and corporate performance. The turning point is 75.38 days. As for the control variables, the results are almost similar to those observed in Table 4. As a further robustness test, we 
estimate our regression model with return on equity $(R O E)$ as a dependent variable instead of return on assets, using both OLS and the fixed effects estimators. Unreported results reveal that working capital measured by both $C C C$ and $N T C$ has an inverted U-shaped relationship with corporate performance measured by $R O E$.

\section{Conclusions}

Working capital management which is one of the fundamental aspects of financial management affects both profitability and liquidity of the firms. This study focuses on the relationship between working capital management and profitability and uses a panel of listed manufacturing companies on the Colombo Stock Exchange (CSE) over the period 2011 to 2016. Two proxies are used to measure working capital namely cash conversion cycle and net trade cycle.

Controlling for unobservable firm specific heterogeneity and a set of observable firm characteristics, our study finds that there is an inverted U-shaped relationship between working capital and firm profitability. That is, the relation between working capital and firm performance is positive at lower levels of WC and it becomes negative at higher levels of WC. Therefore, the findings of this study indicate the existence of an optimal level of working capital for firms that balances the costs and benefits of maintaining working capital and thus maximizes their performance.

\section{Acknowledgement}

Dr. Ratnam Vijayakumaran would like to thankfully acknowledge financial support from the University of Jaffna for this research. Authors have equally contributed to this research.

\section{References}

Abuzayed, B. (2012). Working capital management and firm's performance in emerging markets: The case of Jordan. International Journal of Managerial Finance, 8(2), 155-179. https://doi.org/10.1108/17439131211216620

Aktas, N., Croci, E., \& Petmezas, D. (2015). Is working capital management value-enhancing? Evidence from firm performance and investments. Journal of Corporate Finance, 30, 98-113.

Baker, H. K., Kumar, S., Colombage, S., Singh, H. P. (2017). Working capital management practices in India: Survey Evidence. Managerial Finance, 43, 3. https://doi.org/10.1108/MF-07-2016-0118

Baños-Caballero, S., García-Teruel, P. J., \& Martínez-Solano, P. (2014). Working capital management, corporate performance, and financial constraints. Journal of Business Research, 67(3), 332-338.

Blinder, A. S., \& Maccini, L. J. (1991). The resurgence of inventory research: What have we learned? Journal of Economic Surveys, 5, 291-328.

Deloof, M. (2003). Does working capital management affect profitability of Belgian firms?. Journal of Business Finance \& Accounting, 30(3-4), 573-588. 


\section{Ml Macrothink}

International Journal of Accounting and Financial Reporting

ISSN 2162-3082 2017, Vol. 7, No. 2

Deloof, M., \& Jegers, M. (1996). Trade credit, product quality, and intragroup trade: some European evidence. Financial Management, 25, 33-43.

Ding, S., Guariglia, A., \& Knight, J. (2013). Investment and financing constraints in China: does working capital management make a difference?. Journal of Banking \& Finance, 37(5), 1490-1507.

Dixon, R., Guariglia, A., \& Vijayakumaran, R. (2015). Managerial ownership, corporate governance and firms' exporting decisions: evidence from Chinese listed companies. The European Journal of Finance, 1-39. https://doi.org/10.1080/1351847X.2015.1025990

Ek, R., \& Guerin, S. (2011). Is there a right level of working capital? Journal of Corporate Treasury Management, 4, 137-149.

Emery, G. (1984). A pure financial explanation for trade credit. Journal of Financial and Quantitative Analysis, 19, 271-285.

Eswaran, V. (2015). Shareholders wealth effects of rights and bonus issues: Evidence from Sri Lanka. International Journal of Accounting and Business Finance, 1(2), 1-13.

Fazzari, S. M., Hubbard, R. G., \& Petersen, B. C. (1988). Financing constraints and corporate investment. Brookings Papers on Economic Activity, 1, 141-195.

Gitman, L. J. (1974). Estimating corporate liquidity requirements: A simplified approach. The Financial Review, 9(1), 79-88.

Hill, M. D., Kelly, G. W., \& Highfield, M.J. (2010). Net operating working capital behavior: a first look. Financial Management. 39, 783-805.

Jahfer, A. (2015). Effects of working capital management on firm profitability: empirical evidence from Sri Lanka. International Journal of Managerial and Financial Accounting, 7(1), 26-37.

Jensen, M. C., \& Meckling, W. H. (1976).Theory of the firm: managerial behaviour, agency costs and ownership structure. Journal of Financial Economics, 3, 305-360.

Kamath, R. (1989). How useful are common liquidity measures?. Journal of Cash Management, 9, 24-28.

Kieschnick, R., Laplante, M., \& Moussawi, R. (2013). Working capital management and shareholders' wealth. Review of Finance, 17(5), 1827-1852.

Kim, Y. H., \& Chung, K. H. (1990). An integrated evaluation of investment in inventory and credit: A cash flow approach. Journal of Business Finance and Accounting, 17, 381-390.

Koperunthevi, K. (2010). Working capital management and firms' performance: An analysis of Sri Lankan manufacturing companies. Wayamba Journal of Management. 1(2), 88-98.

Lamberson, M. (1995). Changes in working capital of small firms in relation to changes in economic activity. American Journal of Business, 10(2), 45-50. https://doi.org/10.1108/19355181199500015 


\section{MlMacrothink}

International Journal of Accounting and Financial Reporting ISSN 2162-3082 2017, Vol. 7, No. 2

Lazaridis, I., \& Tryfonidis, D. (2006). Relationship between working capital management and profitability of listed companies in the Athens Stock Exchange. Journal of Financial Management and Analysis. 19(1), 26-35.

Lewellen, W., McConnel, J., \& Scott, J. (1980). Capital market influences on trade credit policies. Journal of Financial Research, 3, 105-113.

Long, M. S., Malitz, I. B., \& Ravid, S. A. (1993). Trade credit, quality guarantees and product marketability. Financial Management, 22, 117-127.

Martínez-Solano, P., \& García-Teruel, P. J. (2007). Effects of Working Capital Management on SME Profitability. International Journal of Managerial Finance, 3(2), 164-177. https://doi.org/10.2139/ssrn.894865

Ng, C. K., Smith, J. K., \& Smith, R. L. (1999). Evidence on the determinants of credit terms used in interfirm trade. Journal of Finance, 54, 1109-1129.

Nimalathasan, B. (2010). Working capital management and its impact on profitability: A study of selected listed manufacturing companies in Sri Lanka. Information Management, 12, 76-83.

Pandey, I. M., Gupta, J. P., \& Perera, K. L. W. (1997). Working capital management: Policies and practices in Sri Lanka, Journal of Euro-Asian Management, 3(1), 74-97.

Perera, K. L. W., \& Wickremasinghe, G. B. (2010). Working capital management practices of manufacturing sector companies in Sri Lanka: survey evidence. Investment Management and Financial Innovations, 7(4), 34-38.

Petersen, M., \& Rajan, R. (1997). Trade credit: Theories and evidence. Review of Financial Studies, 10, 661-691.

Sartoris, W., \& Hill, N. (1983). Cash and working capital management. Journal of Finance, $38,349-360$.

Schiff, M., \& Lieber, Z. (1974). A model for the integration of credit and inventory management. Journal of Finance, 29, 133-140.

Shin, H. H., \& Soenen, L. (1998). Efficiency of working capital and corporate profitability. Financial Practice and Education, 8 (2), 37-45

Shipley, D., \& Davis, L. (1991). The role and burden-allocation of credit in distribution channels. Journal of Marketing Channels, 1, 3-22.

Smith, K. V. (1978). Reading on the Management of Working Capital, West Publishing Company, 3-21.

Vijayakumaran, R. (2015). Capital structure decisions agency conflict and corporate performance: Evidence from Sri Lankan listed manufacturing companies. International Journal of Accounting and Business Finance, 1(1), 1-14.

Vural, G. (2012). Affects of working capital management on firm's performance: Evidence 


\section{Al Macrothink}

International Journal of Accounting and Financial Reporting

ISSN 2162-3082

2017, Vol. 7, No. 2

from Turkey, 2(4), 488-495.

Wasiuzzaman, S. (2015). Working capital and firm value in an emerging market. International Journal of Managerial Finance, 11(1), 60-79. https://doi.org/10.1108/IJMF-01-2013-0016

Wilner, B. S. (2000). The exploitation of relationship in financial distress: The case of trade credit. Journal of Finance, 55, 153-178.

Zwiebel, J. (1996). Dynamic capital structure under managerial entrenchment. The American Economic Review, 1197-1215.

\section{Notes}

Note 1 . We estimate the pooled OLS regression with cluster robust slandered errors (clustered at the firm level) which are robust to unknown heteroscadasticity and within-firm serial correlation in computing standard errors/t-statistics.

Note 2. We use the Hausman specification test to decide whether fixed effects method (FEM) or random effects method (REM) is econometrically a more appropriate approach to our data. Highly significant Hausman test (Chi square $=69.52, P$-value $=0.000$ ) statistics reveal systematic differences in coefficients between both models, which indicates highly significant firm-specific effects. Therefore, FEM provides better specification for our data relative to REM.

\section{Copyright Disclaimer}

Copyright for this article is retained by the author(s), with first publication rights granted to the journal.

This is an open-access article distributed under the terms and conditions of the Creative Commons Attribution license (http://creativecommons.org/licenses/by/4.0/) 